\title{
The Effects of FDI on Human Capital Stock in Central Asian Turkic Republics
}

\author{
Durmuş Çağrı YILDIRIM *, Özlem TOSUNER ${ }^{* *}$
}

\begin{abstract}
Foreign direct investment contributes to the education level of a country through many channels. On the other hand, educated labor increases foreign direct investment inflows. The subject of this paper is to investigate the contribution of foreign direct investment to the level of education in Central Asian Turkic Republics. In this study, the contribution of FDI to level of education is examined by Panel OLS methodology for 1999-2011 periods in Azerbaijan, Uzbekistan, Kazakhstan and Kyrgyz Republic, except Turkmenistan. As a result of the study, there is not a significant relationship between FDI stock and level of education which is used as an indicator for human capital investment.
\end{abstract}

Keywords: Central Asian Turkic Republics, Foreign Direct Investment, Human Capital Stock, Education, Panel OLS

JEL Code Classification: F5, E6, C1

\footnotetext{
*Phd., Recep Tayyip Erdogan University, Fındıklı School of Applied Sciences, Department of Banking and Finance,Turkey. E-mail: cyildirim81@gmail.com

** Recep Tayyip Erdogan University, Fındıklı School of Applied Sciences, Department of International Trade and Logistics. Turkey. E-mail: ozlem.tosuner@gmail.com
}

Copyright @ , 2014 International Ataturk Alatoo University. 


\section{Introduction}

The economic growth of a country is positively linked with the level of FDI inflows. The increasing FDI inflows leads to an increase in the demand for skilled labor and trained professionals for the management of technical, managerial and professional positions has increased. Then human capital development is essential for sustainable social and economic development (Afza and Nazir, 2007: 173).

Foreign direct investment and human capital accumulation are considered as main sources of economic growth. While they both affect growth, they also affect each other through complementarity. Human capital of a country makes investment attractive for foreign investors. On the other hand, multinational enterprises can provide education and training actively, bring new skills, technology and knowledge with them (Miyamoto, 2003: 9).

Michie stated that there are three benefits of human capital accumulation for developing countries to be able to absorb new technologies. First, human capital accumulation leads to higher productivity and profitability as a direct effect. Second, employees are better qualified to absorb and use codified and tacit knowledge. And thirdly, human capital accumulation improves the willingness, commitment and motivation of employees (Michie, 2001: 4).

Foreign direct investment flows towards developing countries and transition economies increase enormously. The main reason for the large share of FDI going in those countries is their large investment in knowledge which developed skilled labor force that are capable of adopting technological innovations (Khan, 2007: 6). FDI is perceived as an important source of capital by developing countries. Low skills and inadequate training level affects FDI negatively and so decreases the capital inflows to the host country. Countries with higher human capital stock attract more FDI inflows (Dutta and Osei-Yeboah, 2010: 1).

Due to the lack of skilled labor in developing countries, the increase in demand of that labor as a result of FDI inflows causes an increase in wages of skilled labor and individual's incentive to acquire more education raises. However the causality relation may be from higher education to foreign direct investment (Zhuang, 2008: 206).

Dutta and Osei-Yeboah (2010) examined the relationship between human capital and FDI level for 76 developing countries over 1980-2003 period with pooled panel OLS. As a measure of human capital, literacy rate and enrollment rates in different education levels as a percentage in the total population are used along with the FDI/GDP ratio and some other determinants of FDI inflows. According to the results, literacy rate has a positive and significant effect on FDI inflows. As for the other levels of education high level primary school enrollment rate leads to higher FDI inflows. The relationship between secondary and tertiary education and FDI is nonlinear. 
Heyuan and Teixeira (2010) tested the direct and indirect impacts of human capital on FDI on microeconomic level with data from a survey conducted for 78 firms in 2008 by logit model. According to the results human capital has no direct effect on FDI for Chinese case and R\&D activities have negative impact on FDI when human capital is measured by academic qualifications. However, there is a positive indirect effect on FDI through R\&D efforts. Also universities and transport network contribute to foreign direct investment.

Majeed and Ahmad (2008) investigated the effect of human capital on attracting FDI in 23 developing countries over 35 years period 1970-2004, by using fixed effects model. The results showed that health expenditure as measure of human capital has a positive and significant effect on FDI inflows, because the productivity of labor force depends on their health and good health improves the learning ability of workers (Majeed and Ahmad, 2008: 98). Also the impact of illiteracy on FDI inflows is negative but not significant, since higher illiteracy rate means labor force is unskilled.

Borensztein \& De Gregorio and Lee (1995) studied the effect of FDI inflows on economic growth using FDI flows from industrial countries to 69 developing countries. The results stated that FDI is an important component for technology transfer. Also there is a strong effect between FDI and human capital; it is that the contribution of FDI to economic growth improves by its interaction with the level of human capital in host country.

The country experiences show that countries with strong human capital attract FDI in high value added products. Rasiah (2005) found out that in countries whose initial human capital endowments are low, FDI helped to raise human capital force to compensate the shortage. The result of this paper shows that for attracting high value added FDI, middle income countries must have the capacity to provide human capital.

Zhuang (2008) examined the effect of FDI flows on human capital accumulation in 29 provinces of China. The data covers between 1978 and 1999. The paper used the college education, professionals and technical education, high school education, middle school education as a percentage of population to capture the effect of FDI in Special export zones (SEZ) and economic and technological development zones (ETDZs) on different education levels. The results stated that the increase in average schooling is about $2.7 \%$ after ETDZs in 1980s. This result is not statistically significant because it is a broad measure of human capital. In 1980s the estimation with the share of rural population with college education states that the relative increase in college education in ETDZs provinces is not greater than the provinces without it.

The estimation with the share of rural population with college education states that the relative increase in college education in ETDZs provinces is not greater than the provinces without it in 1980s. Also the impact of ETDZs on middle school education 
is larger than the high school education. The ETDZs cause $1.16 \%$ relative decrease in rural population with high school education, but $2.65 \%$ increase in rural population share with middle school education. Establishing further ETDZs increase the both college and professional and technical education in these provinces for 1990s. In this era FDI was from North America, EU and Japan whose firms are in capital and technology intensive sectors. So FDI in these sectors increases the demand for well educated labor and results in higher human capital stock for China.

According to Blomström and Kokko, there is two-way causality between FDI and human capital. FDI leads to potential knowledge spillover for host country's labor force, and also the human capital level of the host country determine the amount of FDI that can be attracted (Blomström and Kokko, 2003: 4). As a result of the paper, even the effect of FDI on primary and secondary education is very small; its effect on tertiary (university) is significant. The demand of skilled labor in engineering, natural sciences and business sciences by multinational companies encourages students to complete their tertiary education and as result of this, governments invest more in higher education (Blomström and Kokko, 2003: 12).

Adefabi (2011) tested the interaction between FDI, human capital and economic growth for 25 countries of Sub-Saharan Africa. According to the results, the effect of FDI on economic growth is positive; however it is not through human capital accumulation. As a reason for this, the writer stated that type of education could be more important than the level.

Checchi, De Simone and Faini (2007) analyzed the relationship between FDI and education by using 112 countries for unbalanced panel data for secondary enrollment and 108 countries for tertiary enrollment. Secondary enrollment is related to the development level of the country. 10 percent increase in FDI stock decreases the secondary enrolment rate by $0.24 \%$ and increases the tertiary enrolment rates by $0.17 \%$. If data regressed by fixed effect model, the results show that secondary enrolment is statistically significant and affects FDI inflows positively. Overall, the presence of foreign firms in the host country's economy has a significant effect on tertiary enrollment, because FDI creates job opportunities for skilled labor.

Egger, et.al. (2005) studied the impact of capital market integration on higher education and economic growth by using FDI as capital inflows. Data of 87 countries for the period of 1960-2000 were regressed to put forward the impact of capital market integration on higher education and economic growth. As a result of this estimation for a given public education expenditure, capital market integration causes an increase in the share of high skilled labor. The effect of net capital inflows that is measured by FDI on higher school participation is significant and positive. 
In the literature papers researching the relationship between FDI and education generally study the effects of education on FDI. The main contribution of this paper is researching the contribution of FDI on education in the developing Central Asian Turkic Republics. This paper constitutes from two parts. In the first part consists of data and methodology. Data set and methodology and estimated model are explained in details. The third part of the paper elaborates the results of the analysis.

\section{Data and Methodology}

Central Asian Turkic Republics are Azerbaijan, Uzbekistan, Kazakhstan, Kyrgyz Republic and Turkmenistan. However there is not available data for Turkmenistan. Therefore the country is removed from the analysis. The data are annual and obtained from World Bank and Interstate Statistical Committee of The Commonwealth of Independent States for 1999-2011 periods.

This analysis focuses on the relationship between FDI and human capital series. In the literature studies examining this relationship use a variety of education indicators. In other words, education indicators are used as a proxy for human capital stock. Some of these generally are primary and secondary schools. However in this analysis tertiary school enrollment rate is thought to related with FDI investments much more than others. Tertiary school provides the necessary qualifications for students to enter professions or programs that are required high skills. The skilled human capital stock related with FDI is educated in tertiary school. Thus in this analysis the proxy indicator of human capital stock is chosen tertiary school enrollment rate. GDP per capita_is one of the main determinants of education availability. GDP per capita has theoretically positive effects on education. Openness variable indicates the international trade regime of the country. Inflation rate represents the economic and socio-political stability of the country. Internet usage is a control variable represents the development level of the country. Population is a control variable represents demographic growth rate.

We followed the model that is developed by Mughal and Vechiu (2009) and advanced this model. Firstly we use GDP per capita income differently from the original model. GNI per capita income includes citizens' income of the country earned abroad. However our analysis focuses on the effects of FDI on the education level of citizens live in home country. Thus we decided to use GDP per capita. In the original model agriculture in the value-added of the GDP is used to analyze its significance in human capital growth. In the case of estimating FDI it can be used Agriculture in the value-added of the GDP. In other words this data related with FDI not education. We removed this data from the analysis. Thus our model can be seen in Equation (1).

Tertiary $=G D P_{i t}+\inf$ lation $_{i t}+$ openness $_{i t}+F D I_{i t-1}+$ population $_{i t}+$ int $_{\text {ernet }}+\varepsilon_{i t}$ 
In Equation (1), Tertiary: Tertiary enrollment rate includes public and private schools and full and part time education systems. This data is formed with the total number of students enrolled at public and private tertiary education institutions. Tertiary education is largely based on theoretical knowledge and is intended to provide sufficient qualifications for gaining entry into advanced research programs and profession with high skills requirements. Foreign Direct Investment, net inflows (\%GDP): Foreign direct investment data are the net inflows of investment which is calculated as total of equity capital, reinvestment of earnings, other longterm capital, and short-term capital as shown in the balance of payments. Openness indicates the difference between exports and imports of the countries as percentages of GDP. GDP consists of per capita Gross Domestic Income values. Data are in current US dollars. GDP series are transformed from domestic currencies using single year official exchange rates. Inflation: Inflation figures constitute of the consumer price index which reflects the annual percentage change in the cost of acquiring a basket of goods and services for an average consumer. Population is the population growth rate. Internet is referred to number of people with access to the worldwide network.

GDP, inflation, internet and tertiary series that are subject to analysis are in natural logarithm. The other series in the analysis are included as percentage ratios. Equation (1) will be used for investigation the relationship between series.

Panel data analysis method will be used to examine the relationship between series. Panel data method can be applied both for horizontal and vertical crosssectional data sets. Panel OLS model:

$$
Y_{i t}=\alpha_{i t}+\beta_{1} \chi_{1 i t}+\ldots+\beta_{k} \chi_{k i t}+\varepsilon_{i t}
$$

where $i: 1,2, \ldots, N ; t: 1,2, \ldots, T$.

Two different models can be used for investigating the relationships between series in panel OLS analysis. These models are fixed effect and random effect models.

Fixed effect model includes an individual effect which is constant over time and common across economic agents. This model can be estimated using Ordinary Least Squares estimator. Individuals' state may be guiding for the selection of model while choosing among these models. For example, for members of a certain group of countries (OECD, EU, EMU, etc) fixed model should be applied. In fixed effect model:

- $\alpha_{i t}$ is possibly correlated with $\chi_{i t}$

- Regressor of $\chi_{i t}$ can be endogenous

- can consistently estimate $\beta$ for time-varying $\chi_{i t}$

- cannot consistently estimate $\alpha_{i t}$ if short panel prediction is not possible 
- $\beta=\partial E\left[y_{i t} \mid \alpha_{i t}, \chi_{i t}\right] / \partial \chi_{i t}$

In random effect model $\alpha_{i t}$ is random. Thus the errors: $\varepsilon_{i t}=\alpha_{i t}+u_{i t}$. And OLS estimator is inefficient. In random effect model:

- $\alpha_{i t}$ is purely random

- Regressor of $\chi_{i t}$ must be exogenous

- Corrects standard errors for equi-correlated clustered errors

- prediction is possible

- $\beta=\partial E\left[y_{i t} \mid \chi_{i t}\right] / \partial \chi_{i t}$

Because, countries examined in this study are not members of a group, random effect model can be estimated. However we estimated two models to be able to compare.

\section{Empirical Analysis}

The stationarity condition should be investigated before starting to examine the relationship between the series. Various tests can be run to study the stationarity of series. In this paper Levin, Lee and Chu (2002) test which is one of the stationarity tests in panel data analysis will be applied.

The estimation equation and hypothesis for LLC test are (Levin, Lin and Chu 2002: 1-24; Asteriou and Hall, 2007):

$$
\begin{aligned}
& \Delta y_{i t}=\delta y_{i t-1}+\sum_{L-1}^{P_{i}} \theta_{i L} \Delta y_{i t-L}+\alpha_{m i} d_{m t}+\varepsilon_{i t} \quad \mathrm{~m}=1,2,3, . \\
& H_{0}: \rho=0 \text { and } H_{1}: \rho<0
\end{aligned}
$$

Table 1 shows the test results of stationarity test. The results of the analysis show that the series contain trend and fixed effects. For this reason, the model with trend and constant is taken into consideration while examining stationarity conditions. The results in Table 1 show that LTER series appear to be not stationary and other series are stationary at level values. LTER series becomes stationary at first difference.

The investigation of the relationship between series can be followed after the investigation of stationarity condition. Equation (1) will be estimated in order to study the relationship between series. Two different models will be used to estimate the equation: fixed effect and random effect. The countries included in the analysis have similar features even they are not member of a group. In this context the results of the two models will be examined without a preference between models. If different results obtained from different models, the choice of model will be up to the readers. 
Durmuş Çağrı YILDIRIM \& Özlem TOSUNER

Table 1: LLC Test Results

\begin{tabular}{lcccccc}
\hline Variables & $\begin{array}{c}\text { NONE } \\
\text { (Without Individual } \\
\text { Intercept and Trend) }\end{array}$ & Prob. & $\begin{array}{c}\text { Individual } \\
\text { Intercept }\end{array}$ & Prob. & $\begin{array}{c}\text { Individual } \\
\text { Intercept } \\
\text { and Trend }\end{array}$ & Prob. \\
\hline LTER & 2.832 & 0.997 & -6.289 & 0.000 & -0.476 & 0.317 \\
\hline FDI & 1.069 & 0.857 & -0.992 & 0.160 & -4.270 & 0.000 \\
\hline LGDPPC & 5.440 & 1.000 & -0.328 & 0.371 & -3.019 & 0.001 \\
\hline LINF & -2.318 & 0.010 & -3.018 & 0.001 & -6.928 & 0.000 \\
\hline POP & 0.008 & 0.503 & 0.566 & 0.714 & -2.544 & 0.005 \\
\hline OPEN & -0.354 & 0.361 & -0.523 & 0.300 & -2.363 & 0.009 \\
\hline LINT & -4.540 & 0.000 & -12.921 & 0.000 & -13.430 & 0.000 \\
\hline DTER & -6.643 & 0.000 & -4.923 & 0.000 & -4.158 & 0.000 \\
\hline
\end{tabular}

* The lags are determined according to Schwarz information criterion.

The results of relevant models are shown in Table 2 and Table 3. They show the test results of fixed effect and random effect models respectively. When the test results are analyzed, it can be seen that FDI series has no impact on DTERM series. In other words, foreign direct investment in Central Asian Turkic Republics has no positive contribution to the level of quality education.

Table 2: The Results of Fixed Effects Model

\begin{tabular}{|c|c|c|c|c|}
\hline \multicolumn{5}{|c|}{ Dependent Variable: DTER } \\
\hline \multicolumn{5}{|c|}{ Variable Coefficient } \\
\hline $\mathrm{C}$ & 0.467261 & 0.164568 & 2.839317 & 0.0072 \\
\hline$F D I(-1)$ & -0.000662 & 0.001131 & -0.584733 & 0.5622 \\
\hline LGDPPC & -0.061241 & 0.028298 & -2.164160 & 0.0368 \\
\hline LINF & 0.027380 & 0.014884 & 1.839558 & 0.0737 \\
\hline LINT & -0.001649 & 0.010908 & -0.151165 & 0.8806 \\
\hline POP & -0.041877 & 0.018969 & -2.207629 & 0.0334 \\
\hline OPEN & 0.001690 & 0.000571 & 2.958482 & 0.0053 \\
\hline R-squared & 0.659660 & \multicolumn{2}{|c|}{ Durbin-Watson stat } & 1.346737 \\
\hline Adjusted R-squared & 0.579053 & & & \\
\hline
\end{tabular}

Table 3: The Results of Random Effects Model

\begin{tabular}{lcccr}
\hline Dependent Variable: DTER & Coefficient & Std. Error & t-Statistic & Prob. \\
\hline Variable & 0.309677 & 0.103768 & 2.984328 & 0.0048 \\
\hline C & $-4.28 E-06$ & 0.000863 & -0.004960 & 0.9961 \\
\hline FDI(-1) & -0.029235 & 0.015375 & -1.901385 & 0.0643 \\
\hline LGDPPC & 0.010164 & 0.008300 & 1.224611 & 0.2277 \\
\hline LINF & -0.008981 & 0.008160 & -1.100728 & 0.2774 \\
\hline LINT & -0.059363 & 0.015394 & -3.856124 & 0.0004 \\
\hline POP & 0.001554 & 0.000539 & 2.884447 & 0.0062 \\
\hline OPEN & 0.621546 & Durbin-Watson stat & 1.172388 \\
\hline R-squared & 0.566162 & & & \\
\hline Adjusted R-squared & \multicolumn{5}{l}{}
\end{tabular}




\section{Conclusion}

FDI and human capital are considered as main sources of economic growth. While affecting growth, they also affect each other. High level of human capital attracts foreign investment in a country. In return, multinational companies bring knowledge, technology and new skills with them and provide education and training. Also, FDI inflows provide a conduit for transferring technology from developed to developing countries. Alongside this, FDI is an important source of capital for developing countries without enough capital and is linked with human capital positively. For attracting high levels of FDI, a country should have high human capital stock. Skilled labor and trained professionals attract FDI inflows enormously. The spillover effects of FDI rely on human capital stock in the developing country. For these reasons, developing countries are trying to enhance foreign direct investment inflows.

In this study, the contribution of FDI to level of education was examined by Panel OLS methodology for 1999-2011 periods in Azerbaijan, Uzbekistan, Kazakhstan and Kyrgyz Republic. As a result, foreign direct investment does not promote the level of education in these countries.

The one of the reasons that FDI series has no statistically significant impact on tertiary school enrollment rate can be considered to be the structure of FDI initially made in Central Asian Turkic Republics. Secondly, when investments do not require advanced technology and skilled labor, no impact of FDI on education is expected. Thirdly, the accumulation of human capital cannot be enough for the spillover effects of FDI on education in Central Asian Turkic Republics.

From the perspective of multinational companies (MNCs), they provide sponsorship or give scholarships to talented/gifted students in countries where they need to ensure a qualified workforce. MNCs support and promote the universities through many channels to meet the needs. MNCs especially support tertiary education. The contribution of MNCs to human resources can be through training organized by the company. However, according to the results of the analysis, the contribution of FDI to education level is not consistent with theoretical expectations in Central Asian Turkic Republics. The reason is that, MNCs may not contribute to the planning of education policies in the country or they may not invest in high technology production which needs skilled labor.

In this context, the country's expectations from foreign investors may conflict with the actual contribution of the investor to the country. As a result, FDI towards these developing countries should be selected according to their willingness in investment on high technology sectors and contribution to social and economic development. Thus, human capital as one of the main sources of social and economic development can be maximized. 


\section{References}

Adefabi, Rasak Adetunji (2011) "Effect of FDI and Human Capital on Economic Growth in Sub-Saharan Africa." Pakistan Journal of Social Sciences 8(1): 32-38. http://dx.doi.org/10.3923/pjssci.2011.32.38

Afza, Talat and Nazir, Mian Sajid (2007) "Economic Competitiveness and Human Resource Development: An FDI Perspective." Pakistan Economic and Social Review 45 (2): 167-180.

Asteriou, Dimitrios and Hall, Stephen G. (2007) Applied Econometrics: A Modern Approach Using EViews and Microfit, China: Palgrave MacMillan.

Blomström, Magnus and Kokko, Ari (2003) "Human Capital and Inward FDI." CEPR Working Paper: 167.

Borensztein, E.; De Gregorio, J. and Lee, J.W. (1995) "How Does Foreign Direct Investment Affect Economic Growth?" NBER Working Paper No. 5057.

Checchi, D.; De Simone, G. and Faini, R. (2007) "Skilled Migration: FDI and Human Capital Investment." IZA Discussion Paper No. 2795.

Dutta, Nabamita and Osei-Yeboah, Kwasi (2010) "Foreign Direct Investment and Human Capital: The Role of Political and Civil Rights." Journal of International Development Forthcoming, Available At SSRN: http://ssrn.com/abstract=1263038.

Egger, H.; Egger, P.; Falkinger, J. and Grossmann, V. (2005) "International Capital Market Integration, Educational Choice and Economic Growth." Cesifo Working Paper No. 1630.

Heyuan, Wei and Teixeira, Aurora A. C. (2010) "Is Human Capital Relevant Attracting Innovative FDI To China?" FEP Working Papers No. 388.

Khan, Muhammad Aslam (2007) "Role of Human Capital in Attracting Foreign Direct Investment: A South Asian Perspective." SAARC Journal of Human Resource Development pp.5-25 http://www.shrdc.org/doc/sjhrd/2007/3.\%20Dr.\%20Aslam-Pakistan.pdf

Levin, Andrew, Lin, Chien-Fu and Chu, Chia-Shang James (2002) "Unit Root Tests In Panel Data: Asymptotic And Finite-Sample Properties." Journal of Econometrics (108) 1-24. http://dx.doi.org/10.1016/S0304-4076(01)00098-7

Majeed, Muhammad Tariq and Ahmad, Eatzaz (2008) "Human Capital Development and FDI in Developing Countries." Journal of Economic Cooperation 29 (3): 79-104.

Michie, Jonathan (2001) "The Impact of Foreign Direct Investment on Human Capital Enhancement in Developing Countries." http://www.oecd.org/dev/2731643.pdf. http://dx.doi.org/10.1787/gen_papers-v2008-art4-en

Miyamoto, Koji (2003) "Human Capital Formation and Foreign Direct Investment in Developing Countries." OECD Development Centre, Working Paper No. 211.

Mughal, Mazhar and Vechiu, Natalia (2009) "Does FDI promote higher education? Evidence from developing countries." http://www.umb.no/statisk/ncde-2009/mughalvechiu.pdf.

Rasiah, Rajah (2005) "Human Resources and Foreign Direct Investment with A Focus on the Electronics And Garment Industries." World Bank, Washington D.C., http://siteresources.worldbank.org/INTLM/Publications/20437210/FDI.pdf

Zhuang, Hong (2008) "Foreign Direct Investment and Human Capital Accumulation in China." International Research Journal of Finance and Economics (19): 205-215. 